\title{
A German-Swedish Collection of Histopathological Slides from 1893
}

\author{
By H.-J. Hansen and P.O. Nilsson
}

Laboratory of Pathology, National Veterinary Institute, Uppsala, Sweden.

\begin{abstract}
Hansen, H.-J. and P.O. Nilsson: A German-Swedish collection of histopathological slides from 1893. Acta vet. scand. 1997, 38, 97-107. - A collection of 159 histopathological slides from 1893 was studied as to origin, condition and documentary value. The slides were dated in Leipzig, Germany, September 26 - October 10, 1893. They had apparently been studied jointly by a Swedish veterinary surgeon (Knut August Hjalmar Dahlström) and one or several unknown German colleagues of his in Leipzig, and labelled with their diagnoses. In this paper the collection is referred to as the Leipzig collection. The majority of the slides were well preserved. They reflect part of the animal disease situation, and in some instances also human diseases. Some interesting cases are briefly presented in this paper, one of them even in this abstract, i.e. a case of embryonal nephroma in pig. Six years before Wilms in 1899 described this tumour in children, and 14 years before Day in 1907 described the first case in pig, our then colleagues failed to recognize the embryonic character of the tumour. Their diagnosis was renal adenoma.

About 80 percent of the slides were diagnosed as done according to present day procedure. The quality of the slides and that of the diagnostic skill of which they bear witness certainly reflect the far-reaching progress that was made in the knowledge of the nature of diseases and their causes during the second half of the 19th century.
\end{abstract}

\section{history; 19th century; animal diseases.}

\section{Introduction}

When the Swedish Royal Veterinary College and the Swedish National Veterinary Institute moved from Stockholm to Uppsala in the late 1970s, many objects of historical interest were brought to light. Among them was a collection of histopathological slides from 1893. The objective of this paper is to present the results of a study on the origin, the condition and the documentary value of this collection.

\section{Materials and methods}

The material consists of 159 slides on 8 covered trays (Fig. 1). The slides are provided with labels giving the diagnosis, and in most cases also the species, the organ and/or the tissue from which they were taken (Fig. 2). The hand-written text is in German or Swedish, sometimes both. The handwriting on the labels is, with very few exceptions, written by the same person. The place of origin - Leipzig - is given in 39 cases together with a date somewhere between September 26 and October 10, 1893. The specimens are mounted with Canada balsam on glasses, measuring $33 \times 59 \mathrm{~mm}$, with square cover glasses $(18 \times 18 \mathrm{~mm})$. The routine stain is not specified. Sometimes special stains are mentioned, e.g. gentian violet in a case of amyloidosis, and osmium as "fat stain". Several slides just state "bacillary stain". We studied the slides by light microscopy in order to check 


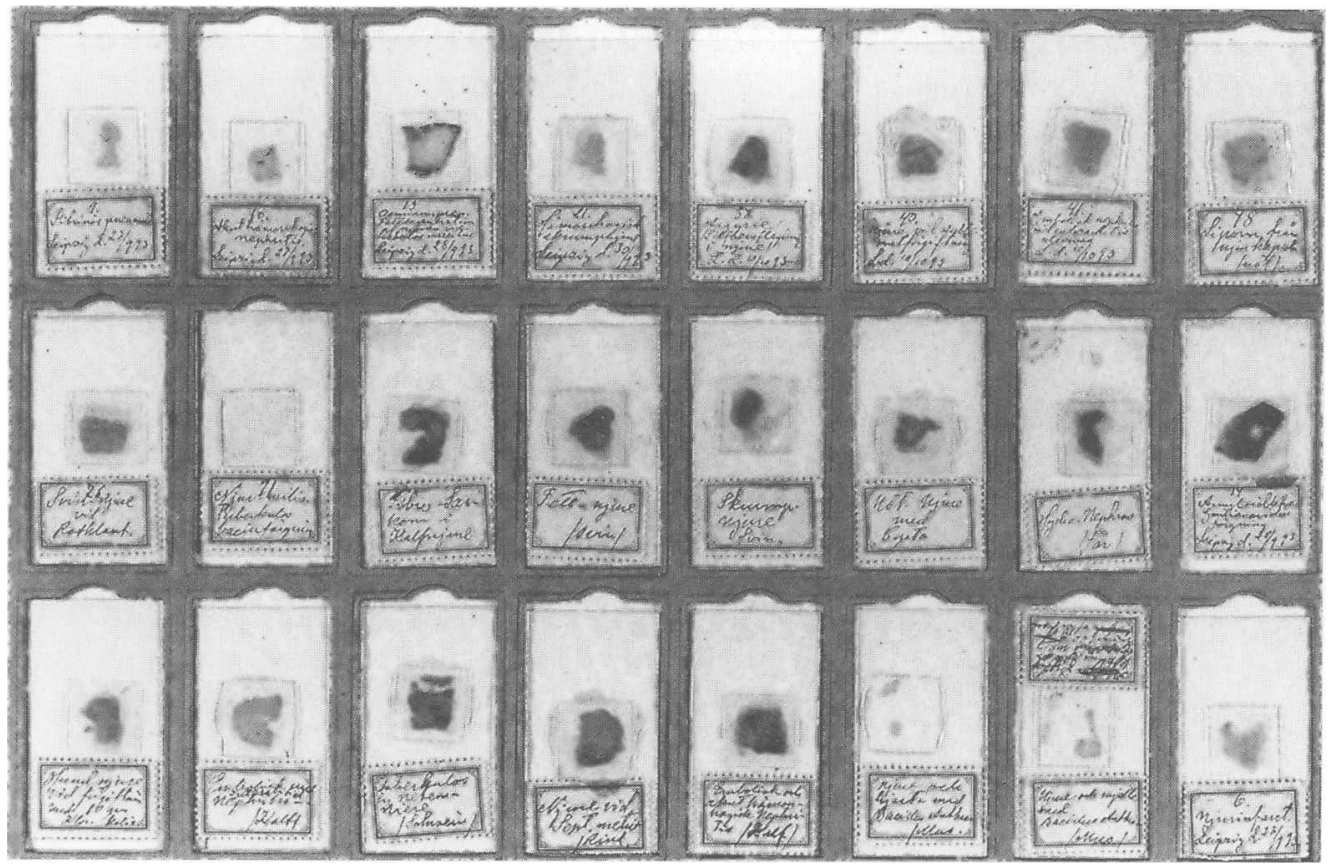

Figure 1. One of the trays (opened).

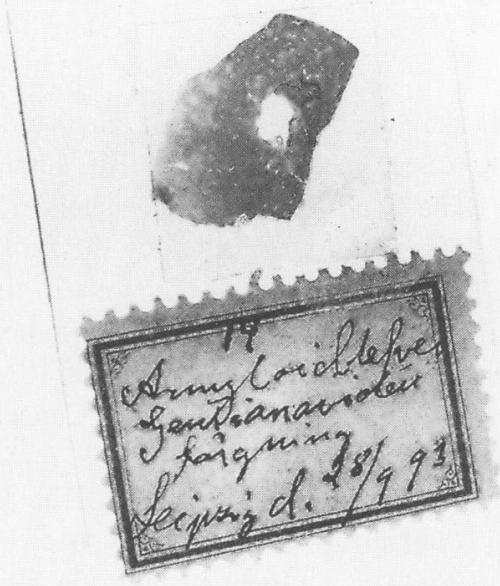

Figure 2. Slide label stating the diagnosis, staining, place of origin and date. the labelled diagnoses. The thickness of the slides from 1893 - an important factor for our study - was measured, using a micrometer screw and compared with that of slides produced today. Ten randomly chosen slides from each group were used. Student's t-test was used for this comparison.

Another question is who the partners in this joint venture were. This matter has called for search in various rolls and archives and also for correspondence with Professor Dr. M. Reinacher, Institute of Pathology, Faculty of Veterinary Medicine, University of Leipzig. The collection will from now on be referred to as the Leipzig collection.

\section{Results and discussion}

The Swedish candidate for the partnership in the production of the Leipzig collection is very 


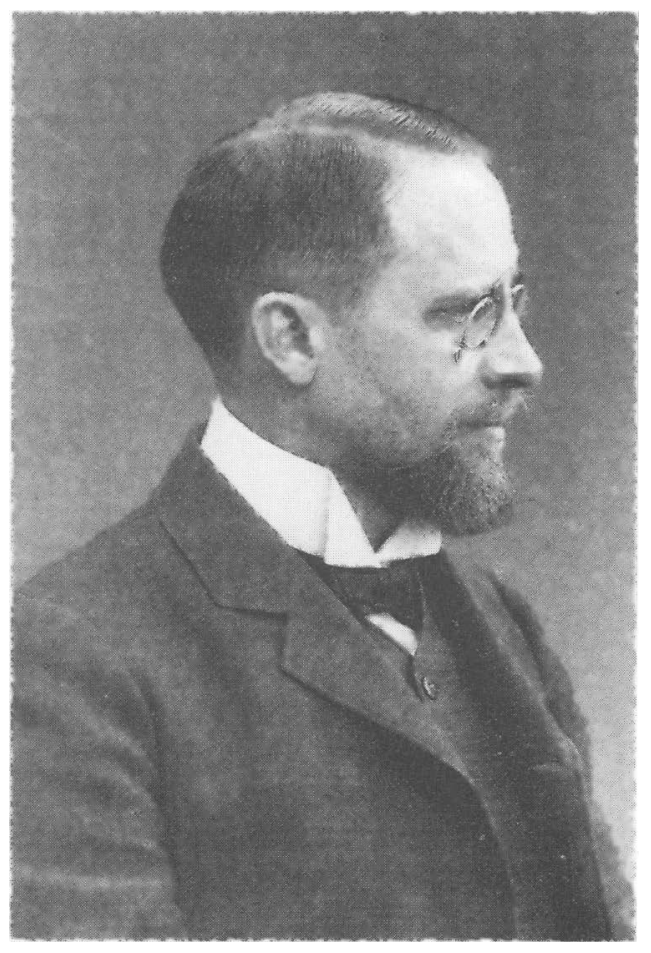

Figure 3. Professor Knut August Hjalmar Dahlström (1868-1935).

likely Knut August Hjalmar Dahlström*. He toured European veterinary schools during the second half of 1893 to study training methods, especially in the clinical subjects. According to his hand-written travel report he visited Leipzig twice - one visit obviously coinciding with the dates given on the labels of the slides. However, he does not comment upon his possible engagement in this matter. One reason could be that the official purpose of his study tour did not include studies in teaching pathology. Another circumstance speaking in favour of his participation might be that he - soon after his return to Sweden - was entrusted with the task of teaching general pathology. Once brought to Sweden, it seems logical to assume that the collection was to be used for teaching purposes.
However, no mention of this collection was found in the annual reports from the Veterinary Institute in Stockholm (the name of the school at that time).

In Leipzig, there was in the late part of the 19th century a Veterinary Institute with - among others - a clinical and polyclinical department, founded in 1878 by Anton Zürn mentioned below. The first professor teaching veterinary subjects was - according to the University calendar for the summer term of 1870 - the emeritus professor of veterinary medicine and Russian privy councillor J.F. Brauell who came from Dorpat (today Tartu, Estonia) to Leipzig. He died in the winter term of 1870/71 and was followed in the chair by professor Anton Zürn. Anton Zürn had a wide knowledge in different veterinary fields, but focussed his research interest on parasitology. Dahlström visited Leipzig in the turn of the months of September/October 1893 and was guided by professor Zürn, whom he found an interesting man. Zürn was a collec-

* Dahlström (1868-1935) Fig. 3, got his higher school certificate (G.C.E) in 1887, entered the Veterinary Institute in Stockholm in the same year and graduated as a Qualified Veterinarian in 1891. He assisted in some teaching at the Veterinary Institute already before graduation and spent some time on postgraduate studies abroad. He was appointed assistant professor of pathology (incl. general pathology) and therapy in 1894, and from 1897 as full professor.

Dahlström held many positions of trust within the veterinary profession. He was secretary of the board of professors, inspector of the Students' Union, Head Librarian of the Veterinary Institute for many years, secretary of the Union of Swedish Veterinarians, board member of many societies for the prevention of cruelty to animals etc. (Frykholm, 1927).

The publications of Dahlström reflect his broad interest for the clinical veterinary medicine, for the social progress of the veterinary profession and for the welfare of animals. His informal, high spirited attitudes made him very popular with the students. 
tor of many things - own artistic drawings, models and pictures, various skeletons and crania of thoroughbred animals, horses' teeth, etc. But again nothing is mentioned in Dahlström's travel report about the slide collection.

The Veterinary Institute of Leipzig was - in 1923 - integrated into the Veterinary Faculty of Leipzig as a research institute for animal epidemics, and later also for animal nutrition. The buildings housing these subjects were destroyed during World War II as were all the documents. Documents dealing with the visit of Dahlström were not found by professor Dr. M. Reinacher or the University authorities, neither could dissection reports concerning the specimens of the kind that has been described in this report be found. For the history of the veterinary institutions mentioned above the readers are referred to Schmidt (1925) and Eber (1928). So, let us return to the condition of the collection. Out of the 159 slides, only 19 are marked by the ravages of time to the extent that it makes a diagnosis impossible. The majority -140 slides - are in relatively good condition. Out of those slides, 122 specimens are more or less correctly diagnosed. In 18 cases only, we cannot agree with the labelled diagnosis.

The slides from 1893 are thicker than our slides of today. This is not due to the thickness of the glasses only, but rather to the sum of the thicknesses of the glasses, the mounting medium and the specimen itself. The difference between the old and the recent material is $0.121 \mathrm{~mm}(0.716$ $0.595 \mathrm{~mm}$ ), giving a t-value of 6.796 . The difference is statistically significant $(p<0.001)$. The thickness of the old slides however, did not significantly hamper our study, but did cause some difficulties in getting sharp photos.

The diagnostic results from 1893 could certainly be attributed to the extensive progress that was made in the knowledge of the nature of diseases and their causes during the second half of the 19th century. In 1858, Virchow intro- duced the concept of cellular pathology. Moreover, the conquests of the microbiological sciences through Pasteur and Koch in the 1880 s-90s, and the discovery by Loeffler \& Frosch (1898) of the first animal virus i.e. Footand Mouth Disease Virus (FMDV) were important achievements. Kitt, pathologist from $\mathrm{Mu}$ nich, edited a manual for histo-pathological techniques in 1889. According to Kitt, fixation was mainly done by absolute alcohol, except for Central Nervous System (CNS-) specimens - alcohol was too rough to the lipids of CNS so potassium bichromate (Müller's solution) was recommended. The material was embedded in paraffin and cut by sledge or hand microtomes. Hematoxylin was used as nuclear stain, and different kinds of carmine for contrast. Finally Canada balsam was used as mounting medium. It is probable that the slides of the Leipzig collection were processed, using the techniques as described by Kitt. The method of cutting, however, cannot be determined.

What do the slides tell us? First of all they certainly reflect part of the disease panorama of the time - tuberculosis, anthrax, glanders, actinomycosis, internal parasitic diseases, salmonellosis, swine erysipelas, various pneumonias, lung emphysema in horses, omphalo-phlebitis, etc. Commenting on each of the slides of the collection would be both unnecessary and tedious. A few of the more spectacular ones will be given a short presentation.

Osmium as a "fat stain". Fatty degeneration of the kidney in diabetes mellitus is presented. Before the introduction of Sudan III IV and others for demonstration of lipid, osmium tetroxide was the reagent most used. Through reduction of the tetroxide to dioxide the lipids became blackened. However, in 1936, Hoerr showed that - depending on the reducing substances used - the blackening could migrate and be adsorbed onto suitable surfaces such as 


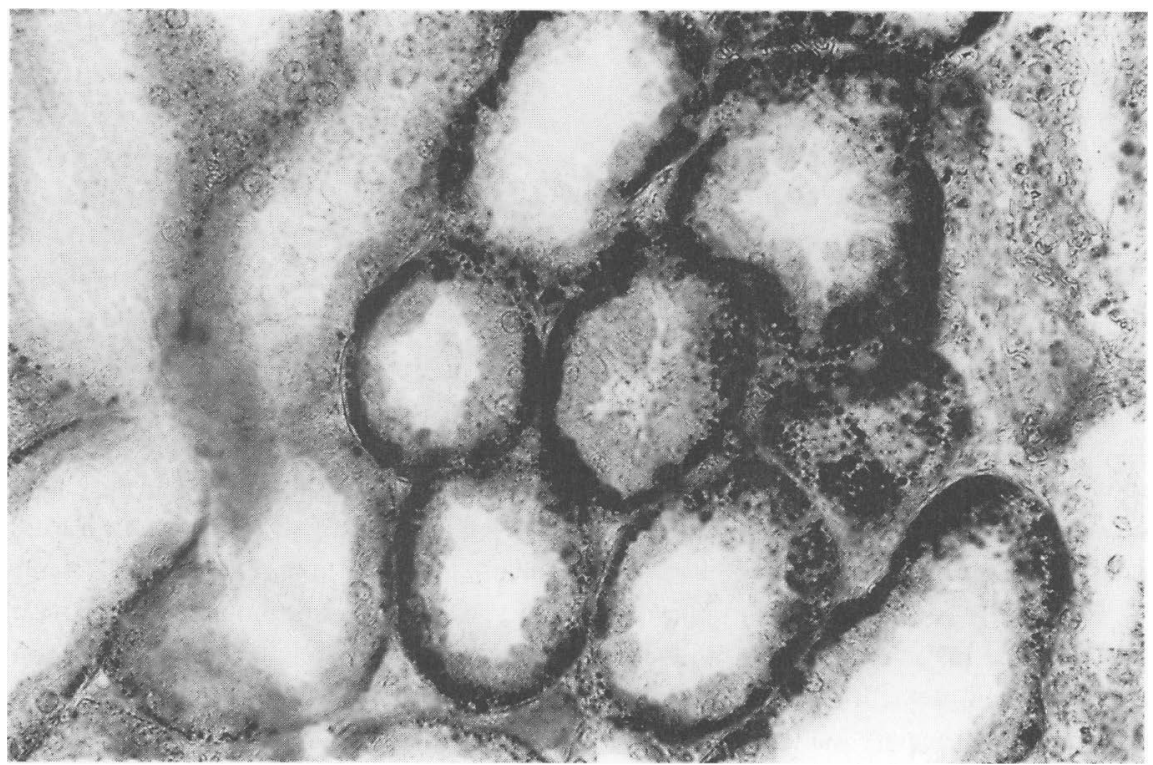

Figure 4. Kidney from a case of diabetes mellitus. Osmium-staining. The lipids are stained black and mainly located to the base of the tubular epithelial cells. $(125 \times)$.

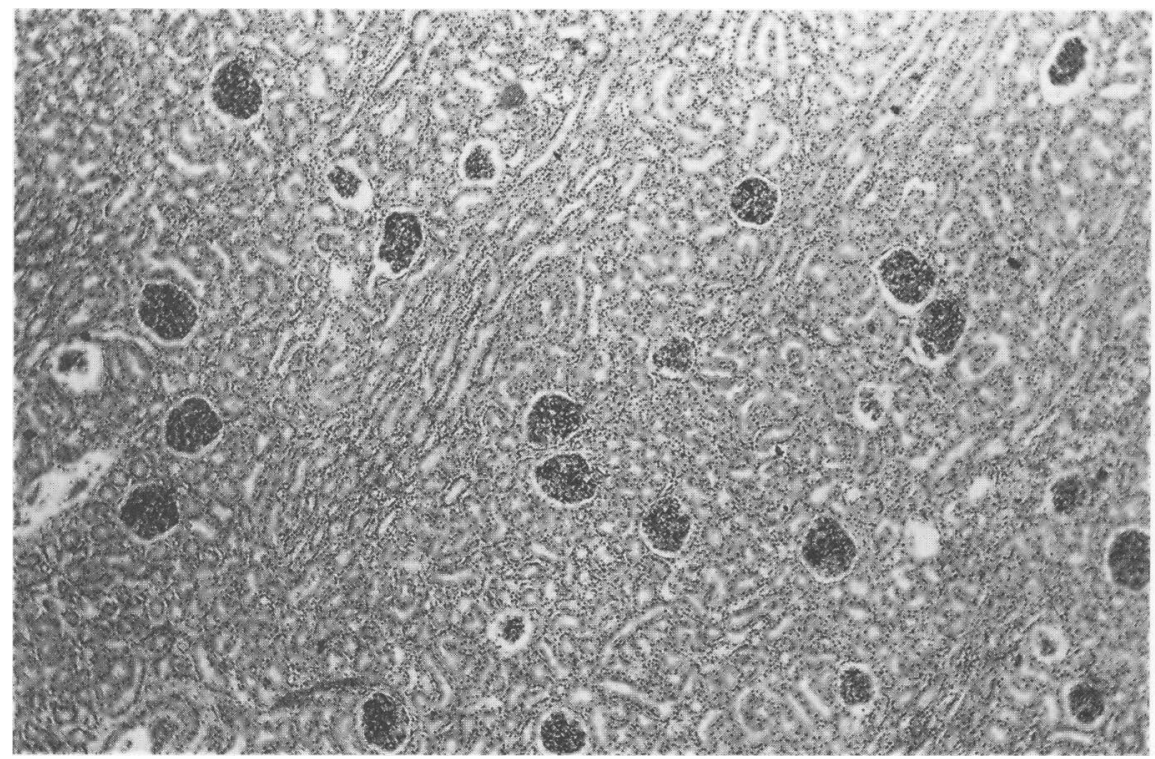

Figure 5. Renal argyrosis. Almost all glomeruli have a black colour due to deposition of silver granules. $(12 \times)$. 
those of various organelles. The specimen of the collection demonstrates this beautifully with the blackening concentrated to the base of the tubular cells (Fig. 4.). Sudan would have shown the lipids as red droplets in the cytosol.

Renal argyrosis. The specimen is most probably taken from a man treated with silver nitrate - according to the custom of the time for ulcus ventriculi. In the glomeruli there is a heavy deposition of silver granules (Fig. 5). The deposits between tubular epithelial cells are less prominent. There are also mild focal cellular and fibrotic reactions.

Liver amyloidosis. Stained with gentian violet. Well preserved metachromasia. The perisinusoidal spaces are heavily loaded with violet homogeneous material. The species is not specified. A qualified guess is the horse, because of the predisposition of hepatic amyloidosis in the equine species. And if so, another guess is a horse used for production of hyperimmune serum, which seems to have been practiced already at that time, at least in a series of experiments by Behring \& Schütz (1892).

Telangiectasis in cattle. This very frequent finding of a spotted liver, generally in cattle, was classified as angiomatosis in 1893 . Today it is considered to be a capillary ectasis of practically no clinical significance. The pathogenesis, however, is still obscure. Mechanical, neural, immunological, degenerative, and dysontogenic factors have been discussed (Stroh in a study on telangiectasis in boar, 1903). Still, the mechanism of this clinically insignificant phenomenon continues to puzzle mainly those interested in the dynamics of blood circulation.

Pneumatosis cystoides intestinorum or intestinal emphysema in pigs is a rare finding. A corresponding lesion can be found also in cattle, sheep and man. The mesentary, the intestinal wall and the mesentary lymph nodes may be studded with thin-walled, gas-filled, cystic dilations of lymphatics. The disease was described as early as 1825 by Mayer. Naeslund (1924) in an experimental, clinical and pathological study of the disease demonstrated gasforming gram-negative bacteria as a possible cause of the disease. The pig case from 1893 shows a very heavy inflammatory reaction in the mucosa with an abundance of eosinophilic leukocytes. The submucosa looks empty, probably due to gas accumulation. In the muscular layers there are a slight to moderate inflammatory, cellular reaction, and some dilated empty spaces. In the serosa there are many small and large, empty spaces with moderate inflammatory reaction in their walls as well as mononuclear cells resembling epithelioid cells.

Typhus-lymphoma probably from a calf, shows heavy cellular necroses in the liver (Fig. 6), typical though not pathognomonic for infections with Salmonella spp - in the calf most commonly S. Dublin and S. Typhimurium. Today, we may call them paratyphoid nodules, paratyphoid granulomata, or simply cellular necroses. We are in agreement with our colleagues from 1893, although we use a somewhat different terminology.

Extramedullary blood formation in the liver was labelled "sheep liver with Distomum eggs". The "eggs" are megakaryocytes (Fig. 7). A few foci of other hematopoetic cells can be seen. The specimen describes extramedullary blood formation, and is probably taken from a young individual.

A lung specimen from a case of swine erysipelas shows a number of bacterial emboli and thrombi. The vessels concerned seem to be arterioles (Fig. 8). There is an acute puru- 


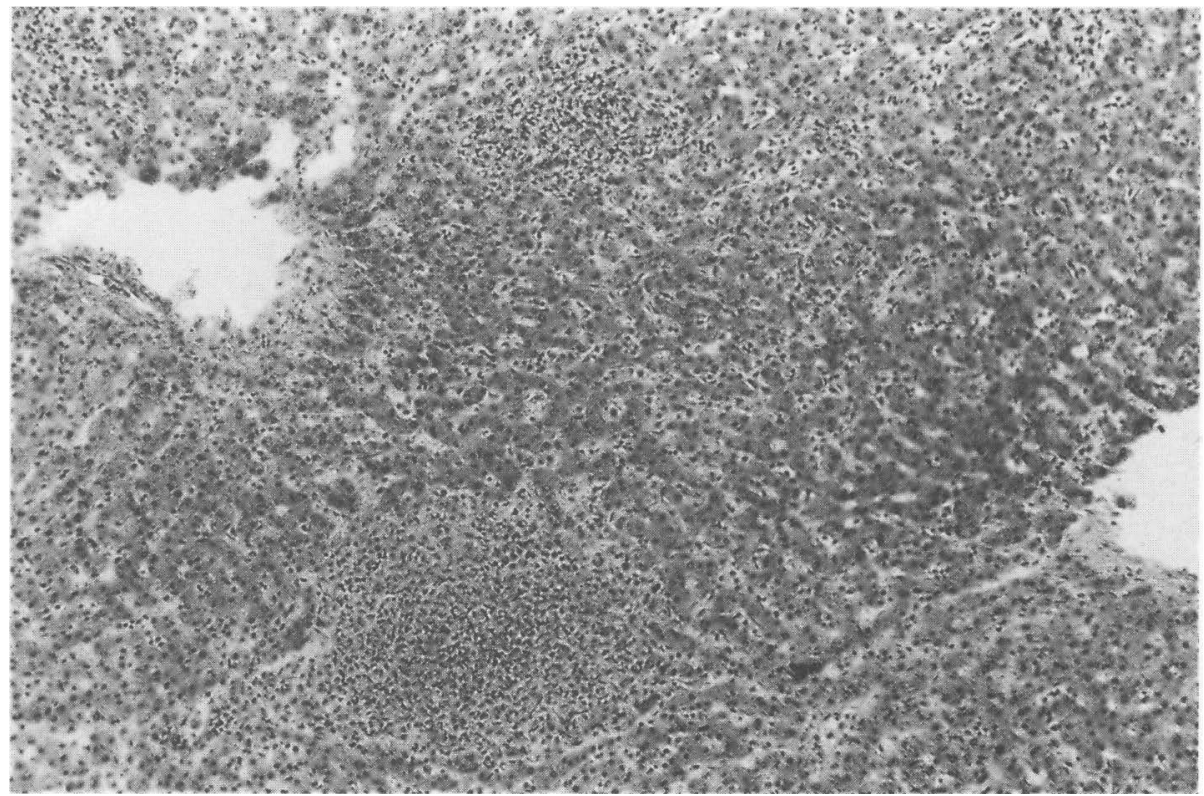

Figure 6. Typhus lymphoma. Liver with focal highly cellular necroses. $(30 \times)$.

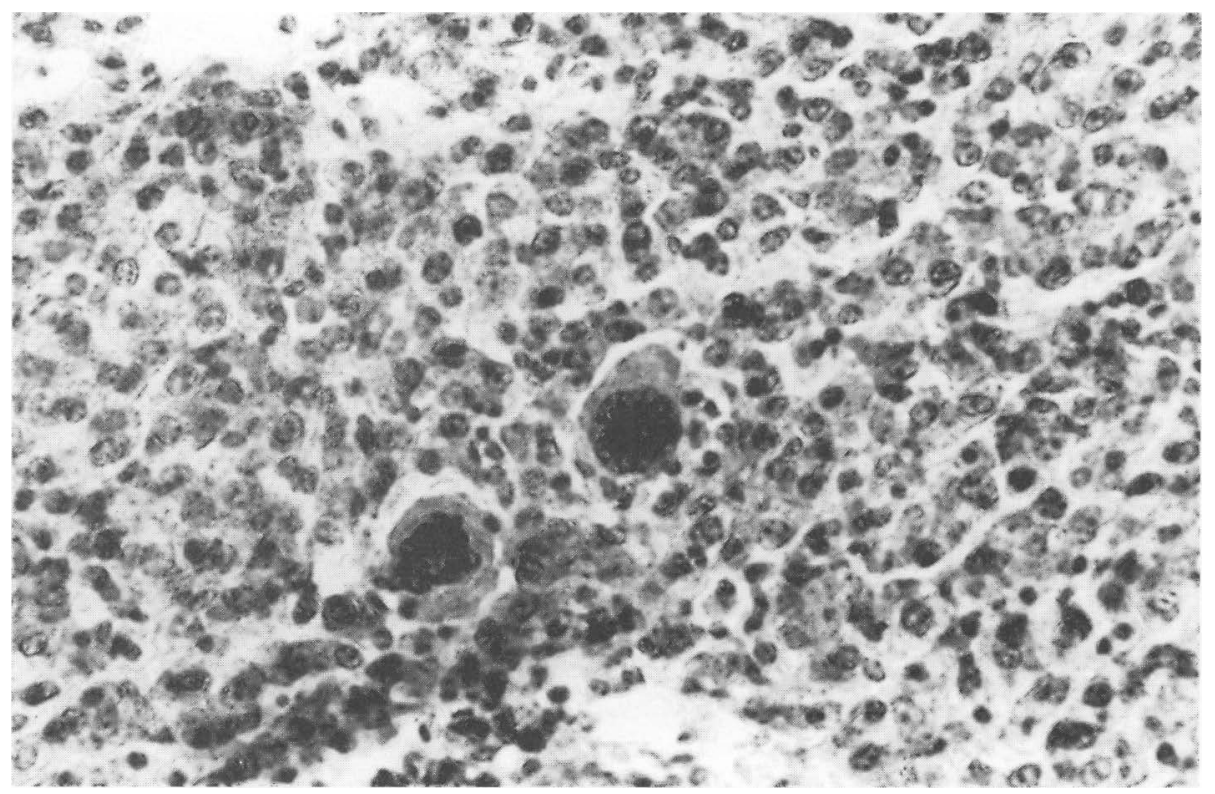

Figure 7. Extramedullary blood formation. Liver with two megakaryocytes. $(125 \times)$. 


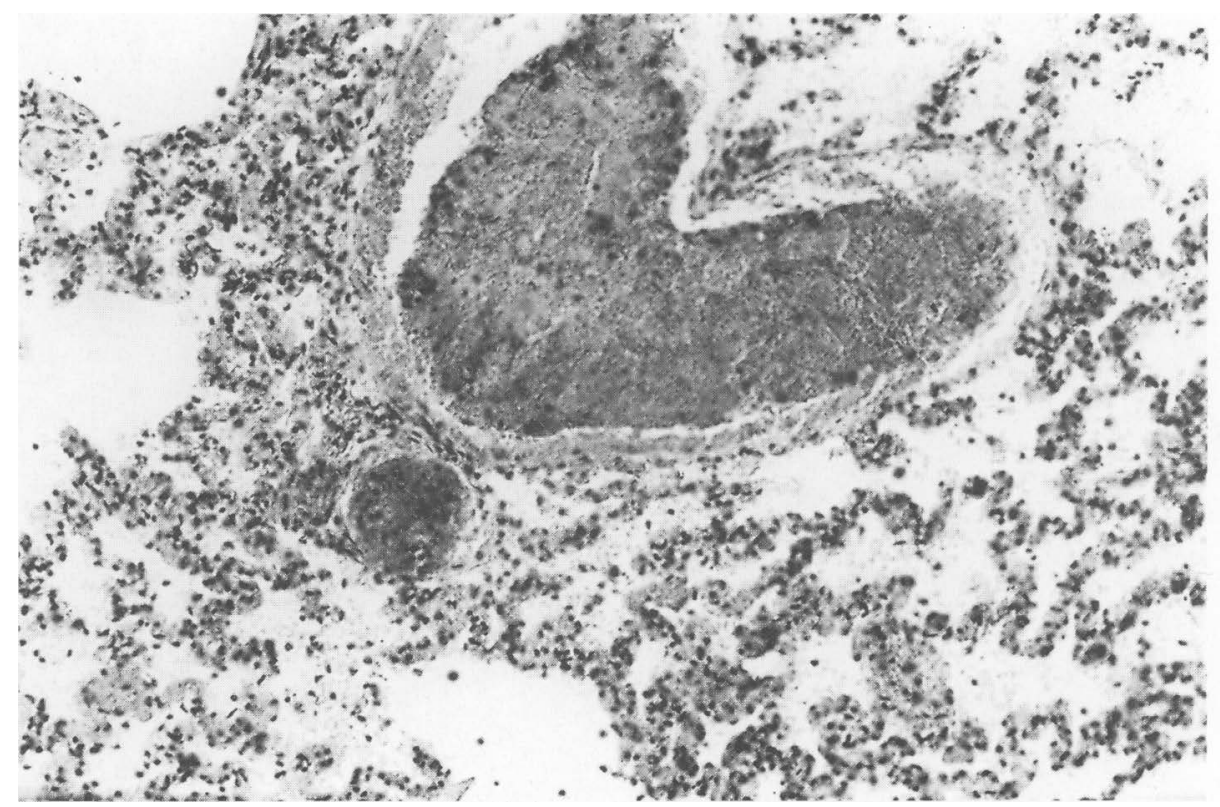

Figure 8 . Swine erysipelas. Lung with vessels containing thrombi. $(30 \times)$.

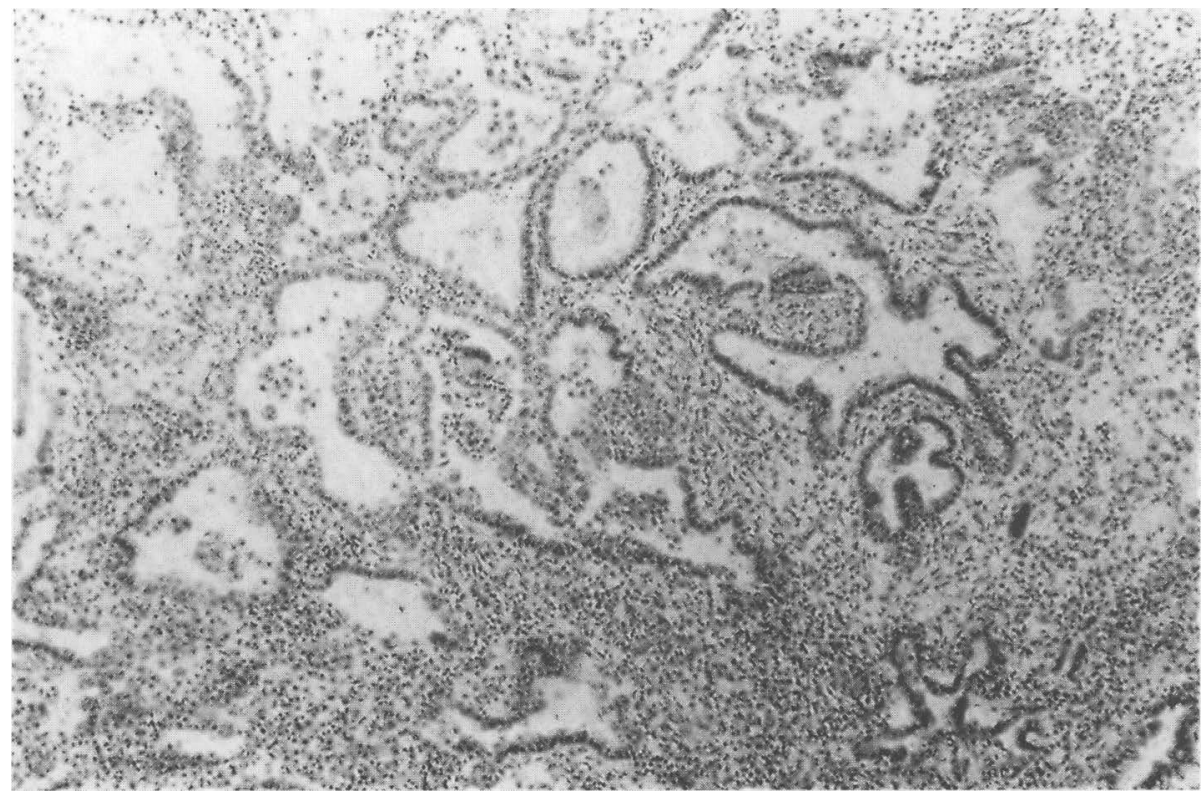

Figure 9. Jaagsiekte. Alveolar spaces lined with proliferated cuboidal-columnar epithelial cells. Papillary projections into the lumina. Signs of interstitiell pneumonia. $(30 \times)$. 


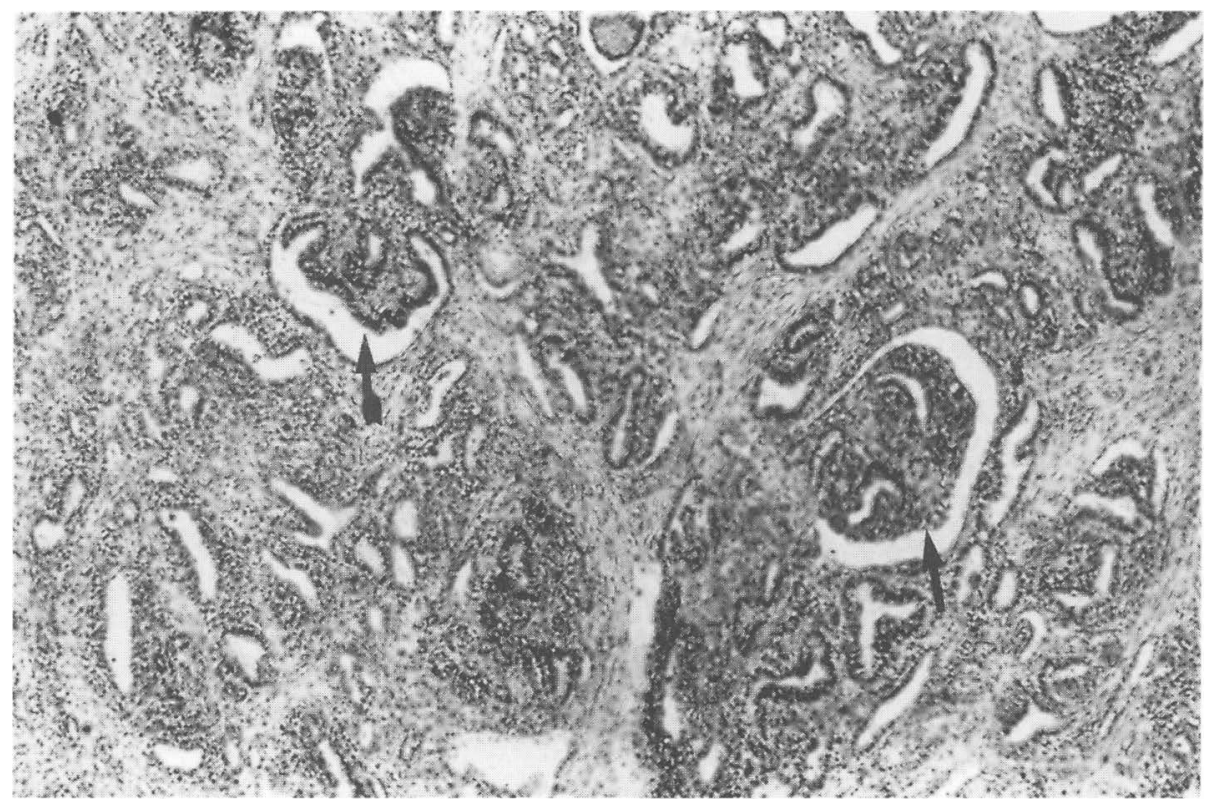

Figure 10 . Embryonal nephroma. The picture is dominated by embryonal tubules and glomeruli like structures (arrows). $(30 \times)$.

lent pneumonia. The picture suggests a fibrinous, valvular endocarditis as the most probable source of the lung lesions.

Jaagsiekte (so called pulmonary adenomatosis) in sheep was recognized as an infectious pulmonary disease in South Africa more than a century ago. The true nature of the infectious agent - jaagsiekte retrovirus (JSRV) - was, however, only recently established as summed up by Verwoerd et al. $(1980,1983)$. Today, the disease is endemic in i.a. most European countries. The pathological picture includes anything from hyperplastic to neoplastic proliferation of type II granular pneumocytes and clara cells. Signs of interstitial pneumonia are present in most cases. The picture may often be complicated by changes due to simultaneous infection with Maedi-virus, bacteria and/or parasites. Our case from 1893 also shows a heavy broncho-interstitial pneumonia of unspecific type (Fig. 9).

Liver-gumma of man. Syphilis has a 3 stage course similar to that of tuberculosis. Also, the tissue changes bear resemblance to those of tbc. The third stage - the "gumma" - has got its name from the central necrosis of the granulomata which has a consistency similar to gum arabic. The cellular pattern of the granuloma is very much the same as in tuberculosis. The granulomata in our specimen demonstrate this similarity between tuberculosis and syphilis.

Embryonal nephroma (nephroblastoma). In 1899 Wilms, Leipzig, described the embryonal nephroma in children. In 1907 Day was the first one to describe this tumor in young pigs and in 1963 Guillon et al. described the tu- 
mour in chicken. In 1893 our colleagues had a case of this interesting mixed embryonal tumour in a pig - in Leipzig! Their diagnosis was adenoma. Six years before Wilms and 14 years before Day! No wonder then that our colleagues did not recognize the embryonal picture of the tumour, but what a pity that they did not! They missed the ever lasting credit for this discovery. Embryonal nephroma in pigs is usually clinically silent - even in spite of its often very large size. It is usually unilateral, so the other kidney can compensate. Thus the tumour usually escapes detection until at slaughter. In Sweden, the incidence of this tumour has increased considerably after the introduction of the Hampshire breed for upgrading the existing 2 breeds - Landrace and Yorkshire. The incidence in pigs crossbred with Hampshire was 18.5/100.000 slaughtered pigs and in the other 2 breeds 1/100.000 (Wiidigs and Nilsson, 1984). The histological picture is that of a mixed tumour. It is embryonic with mesenchymal and epithelial components. In pigs the glomerulo-tubular structures dominate (Fig. 10).

The spirits of Virchow, Pasteur and Koch coined the medical ideas at the end of the 19th century. For the first time pathology - the concept of disease mechanisms in modern time was formulated. An important thing we have learnt from our study of the Leipzig collection is the close agreement between the histopathological diagnostics of those times and today.

It is interesting to note that there are no examples from companion animals (dogs and cats) among the slides. In the early centuries of veterinary medicine the knowledge of health and disease of farm animals was certainly given high priority. The medicine and surgery of pet animals were a produce of the 20 th century. The demand, especially for tumour specimens in the Leipzig collection, was covered by material from laboratories of human pathology. Thus, the Leipzig collection also is a reflection of the growing interest in comparative pathology inspired by the doctrines of cellular pathology. Another example of this trend may be found in the appearance of the comprehensive text-book of comparative pathology published in 1865 by Gleisberg, active in the Dresden-Leipzig area. A sad experience of our study is the loss of documentation behind the material caused by the wars of the 20 th century.

\section{Acknowledgements}

We are grateful to Prof. Dr. M. Reinacher, Leipzig, and Chief Librarian, Vet. Med. Dr. h.c. P-O. Räf, Skara, for helping us to trace people and documents from the late 19th century. Finally, our thanks also go to Mrs. Mona Saxena for prompt secretarial assistance.

\section{References}

von Behring E: Die Blutserumtherapie bei Diphterie und Tetanus. (Blood serum therapy in diphteria and tetanus). Z. Hyg. Infekt.Krankh, 1892, 12, $1-9$.

Dahlström KA Hj: Berättelse öfver studieresa såsom Jacobisk stipendiat sommaren 1893. (A handwritten report (not published) from a study trip as a Jacoby scholar in the summer of 1893) 99pp.

Day LE: Embryonal adenosarcoma of the kidney of swine. 24th Annual Report of the Bureau of Animal Industry (Washington, D.C.) 1907, p. 247.

Eber A: Fünfzig Jahre Veterinärinstitut (jetzt Tierseucheninstitut) der Universität Leipzig. (University of Leipzig Veterinary Institute (now Animal Disease Institute) 50th Anniversary) Dt. Wschr. 1928, 36, 325-330.

Frykholm NTh: Svensk Biografisk Veterinär-Matrikel från 1750 till nuvarande tid. (Swedish Biographical Veterinary Register from 1750 to present time) Uppsala 1927, 77-78.

Fåhraeus R: Läkekonstens historia, III (History of Medicine, III). Bonniers, Stockholm, 1950, pp. 159-171, 210-228.

Gleisberg JP: Lehrbuch der vergleichenden Pathologie. (Text-book on comparative pathology). Leipzig, 1865, pp. 754.

Guillon JC, Chouroulinkov I, Renault L: Les tumeurs rénales spontanées des Gallinaces. (Spontaneous renal tumours in chicken). Bull. Cancer, 1963, 50, 593-620. 
Hansen H-J, Nilsson PO: A set of histopathological slides from 1893, Historia Medicinae Veterinariae 1995, 20:1 and 20:2.

Hoerr NL: Histological studies on lipins - I. On osmic acid as a microchemical reagent with special reference to lipins. The Anat. Rec. 1936, 66, 149171.

Kitt Th: Bacteriologische und Pathologisch-Histiologische Übungen für Thierärzte und Studierende der Thierheilkunde. (Bacteriological and histopathological practices for veterinarians and veterinary students). Wien, Verlag von Moritz Perles, 1889 , pp. 328.

Loeffler F, Frosch P: Berichte der Commission zur Erforschung der Maul- und Klauenseuche bei dem Institut für Infectionskrankheiten in Berlin. (Report of the Commission for the studies of Foot-and-Mouth Disease from the Berlin Institute of infectious diseases). Dt. Med. Wschr., $1898,24,80$.

Mayer: Beobachtungen einer Pneumatosis Cystoides Intestinorum. (Observations on Pneumatosis, cystoides intestinorum). J. prakt. Heilkde, 1825, 61, 67-77.

Naeslund J: Zur Kenntnis der Pneumatosis cystoides intestinorum. (On the knowledge of Pneumatosis cystoides intestinorum). Vet. Diss. Stockholm, 1924, pp. 101.

Schmidt J: Die neue Veterinärmedizinische Fakultät der Universität Leipzig. (The new Faculty of Veterinary Medicine at the University of Leipzig). Berl. Tierärztl. Wschr. Enclosure No 20, 1925, 112.

Schütz: Versuche zur Immunisirung von Pferden und Schafen gegen Tetanus. (Experiments on immunisation of horses and sheep against tetanus). $Z$. Hyg. Infekt. Krankh., 1892, 12, 58-81.

Stroh: Die fleckige Capillarektasi der Eber. (Spotted capillary ectasia in boar). Mh. prakt. Tierheilk. 1903, 4, 133-187.

Verwoerd DW: Jaagsiekte (Ovine Pulmonary Adenomatosis) Virus. In: Dinter Z. and Morein B (eds). Virus Infections of Ruminants, Elsevier, Amsterdam, 1990, 453-463.
Virchow R: Die Cellularpathologie in ihrer Begründung auf physiologische und pathologische Gewebelehre. (The cellular pathology as based on physiological and pathological histology). Berlin 1858.

Wiidigs G, Nilsson $N-G$ : Embryonalt nefrom njurtumör hos främst korsningsgrisar? (Embryonal nephroma - renal tumour in mainly crossbred pigs?). Svensk Veterinärtidning, 1984, 36, 137139.

Wilms M: Die Mischgeschwülste der Niere. (Mixed tumors of the kidneys). A. Georgi, Leipzig, 1899.

\section{Sammanfattning}

En tysk-svensk samling av histopatologiska preparat från 1893.

En samling av 159 histopatologiska preparat (snitt) från 1893 studerades med avsikt att belysa dess ursprung, kondition och dokumentära värde. Samlingen härstammade från Leipzig i Tyskland och var daterad 26 september -10 oktober, 1893 . Den var uppenbarligen sammanställd av den gästande svenske veterinären Knut August Hjalmar Dahlström (18681935) i samarbete med en eller flera tyska kollegor, vars identitet inte gått att fastställa, huvudsakligen till följd av andra världskrigets förstörelse av Leipzig. Majoriteten av snitten var väl bibehållna och försedda med etiketter (diagnos och oftast djurslag). Snitten speglar delar av dåtida sjukdomsflora bland husdjuren och även människans sjukdomar. Ett tiotal mera intressanta fall presenteras kortfattat. Ett särskilt intressant fall, presenterat som renalt adenom, visade sig vara ett embryonalt nefrom. Det var 6 år innan Wilms (1899) beskrev tumörens embryonala karaktär hos barn och 14 år innan Day (1907) upptäckte samma tumör hos gris.

Cirka 80 procent av snitten hade diagnosticerats i enlighet med våra dagars kunskaper. Snittens tekniska kvaliteter och den diagnostiska färdigheten vittnar om de framsteg ifråga om kunskaperna om sjukdomarna och deras orsaker, som gjordes under 1800 -talets senare hälft (Virchow (1858) Pasteur, Koch m. fl.).

(Received April 25, 1996; accepted November 28, 1996).

Reprints may be obtained from: H.-J. Hansen, Laboratory of Pathology, National Veterinary Institute, P.O. Box 7073, S-750 07 Uppsala, Sweden. 
